\title{
PENINGKATAN PENGETAHUAN TENTANG PHBS SISWA SMP NEGERI 1 DULUPI MELALUI PENYULUHAN KESEHATAN, KABUPATEN BOALEMO
}

\author{
Zul Adhayani Arda R ${ }^{1}$ Maesarah², Nur Hamdani Nur³, \\ Nur Aisa Taki4 \\ Prodi Ilmu Kesehatan Masyrakata, Fakultas Kesehatan Masyarakat, Universitas Gorontalo ${ }^{1}$; \\ email:niarda87@gmail.com \\ Prodi Ilmu Gizi, Fakultas Kesehatan Masyarakat, Universitas Gorontalo² ; email: \\ maesarahyasin@gmail.com \\ Prodi Kesehatan Masyarakat, Fakultas Kesehatan Masyarakat, Universitas Pancasakti3; email: \\ hamdani82nur@gmail.com \\ Prodi Kesehatan Masyarakat, Fakultas Kesehatan Masyarakat, Universitas Gorontalo4; email: \\ nuraisyataki@gmail.com
}

\begin{abstract}
Abstrak
Desa Dulupi memiliki jumlah penduduk 4165 jiwa. Berdasarkan hasil pendataan masih ditemukan beberapa masyarakat yang tidak melakukan pola hidup sehat seperti, merokok $(28,7 \%)$, membuang sampah tidak pada tempatnya (46,3\%), dan belum memiliki jamban $(25,7 \%)$. Sehingga dianggap perlu untuk meningkatkan kesadaran dan pengetahuan masyarakat tentang pola hidup sehat melalui penyuluhan kesehatan. Kelompok sasaran untuk kegiatan pengabdian ini adalah anak usia remaja yaitu siswa SMP Negeri 1 Dulupi yang terletak di Kecamatan Dulupi Kabupaten Boalemo. Usia remaja dijadikan kelompok sasaran karena usia remaja merupakan masa transisi dari anak-anak ke masa dewasa yaitu usia 10-19 tahun dengan rasa keingintahuan yang sangat besar. Target siswa dalam kegiatan ini adalah 30 siswa. Jumlah siswa yang dijadikan responden terbatas karena masih dalam kondisi pandemic COVID 19. Metode pengabdian yang dilakukan adalah "Pretest - Penyuluhan - Postest". Materi yang diberikan adalah tentang Perilaku Hidup Bersih dan Sehat (PHBS) dan bahaya merokok. Hasil pengabdian menunjukkan bahwa ada perbedaan pengetahuan siswa sebelum dan ssetelah diberikan penyuluhan yaitu terjadi peningkatan pengetahuan. Dengan peningkatan pengetahuan ini diharapkan dapat meningkatkan kesadaran para siswa untuk selalu menerapkan pola hidup sehat baik di sekolah maupun dalam kehidupan bermasyarakat.
\end{abstract}

Kata Kunci: Penyuluhan Kesehatan, Pengetahuan siswa

\section{Abstract}

Dulupi Village has a population of 4165 people. Based on the results of the data collection, it was still found that some people did not practice a healthy lifestyle such as smoking (28.7\%), throwing garbage out of place (46.3\%), and not having a latrine (25.7\%). So it is considered necessary to increase public awareness and knowledge about healthy lifestyles through health education. The target group for this service activity are teenagers, namely students of SMP Negeri 1 Dulupi which is located in Dulupi District, Boalemo Regency. Teenagers are the target group because adolescence is a transition period from children to adulthood, namely the age of 10-19 years with a very large sense of curiosity. The target students in this activity are 30 students. The number of students who became respondents was limited because they were still in a COVID-19 pandemic condition. The method of service carried out was "Pretest - Counseling - Posttest". The material given is about Clean and Healthy Behavior (PHBS) and the dangers of smoking. The results of the service showed that there was a difference in students' knowledge before and after being given counseling, namely 
an increase in knowledge. With this increase in knowledge, it is hoped that it can increase students' awareness to always apply a healthy lifestyle both at school and in community life.

Keywords: Health Counseling, Student knowledge

\section{PENDAHULUAN}

Undang-Undang Republik Indonesia Nomor 36 tahun 2009 tentang Kesehatan, disebutkan bahwa kesehatan adalah suatu keadaan sehat, baik secara fisik, mental, spiritual maupun sosial yang memungkinkan setiap orang dapat hidup produktif secara sosial dan ekonomis. Kesehatan paripurna ini sangatlah penting buat semua orang tanpa kecuali. Kesehatan harus dipelihara dengan cara pola hidup bersih dan sehat supaya terhindar dari berbagai penyakit. Tetapi tidak semua orang dapat melakukan PHBS. Hal ini disebabkan karena pengetahuan yang rendah, kesadaran yang rendah atau karena adanya pengaruh luar yang lebih kuat (Rahmawati. dkk, 2019).

Pola penerapan hidup bersih dan sehat merupakan bentuk dari perilaku berdasarkan kesadaran sebagai wujud dari pembelajaran agar individu dapat meningkatkan status kesehatan baik pada diri sendiri maupun lingkungan masyarakat. Program penerapan Perilaku Hidup Bersih dan Sehat (PHBS) merupakan bentuk dari upaya untuk memberikan pelajaran berupa pengalaman pada tiap individu, anggota keluarga, sekumpulan, maupun pada masyarakat umum. Pelajaran dapat melalui media komunikasi, pemberian berita, serta pendidikan kesehatan dalam bentuk penyuluhan (Kemenkes RI, 2016).

Hingga saat ini perilaku hidup sehat menjadi satu perhatian khusus terutama bagi pemerintah. Hal ini karena PHBS dijadikan sebagai tolak ukur dalam pencapaian untuk meningkatkan cakupan kesehatan pada program Sustainable Development Goals (SDGs) tahun 2015- 2030. PHBS dalam SDGs merupakan salah satu bentuk upaya pencegahan yang menimbulkan dampak jangka pendek di dalam peningkatan kesehatan pada tiga tempat antara lain, pada lingkup anggota keluarga, masyarakat umum, serta sekolah (Kemenkes RI, 2017). Pedoman Pembinaan PHBS dilaksanakan melalui pendekatan tatanan termasuk institusi pendidikan. Kegiatan PHBS yang bisa dilaksanakan pada institusi pendidikan yaitu cuci tangan, konsumsi jajanan sehat, jamban sehat, olahraga, pemberantasan jentik nyamuk, tidak merokok, membuang sampah dan pengukuran pertumbuhan. Usia remaja sekolah merupakan masa emas untuk menanamkan nilai PHBS karena pada usia ini anak dapat menjadi agen perubahan untuk mempromosikan pola hidup sehat baik di sekolah, keluarga, dan masyarakat (Depkes RI, 2011).

Anak usia sekolah juga merupakan usia yang rentan terhadap berbagai penyakit, terutama yang berhubungan dengan pencernaan, seperti diare, kecacingan, dan gangguan pencernaan lainnya. Kebiasaan anak-anak mengkonsumsi jajanan secara bebas, ditambah anak-anak tidak melakukan mencuci tangan menggunakan sabun sebelum makan akan mengakibatkan berbagai kuman penyebab penyakit mudah masuk ke dalam tubuhnya (Aeni. dkk, 2016). 
Pencanangan Program Pembinaan PHBS sebenarnya sudah lama dilakukan oleh pemerintah, namun nyatanya keberhasilan dari program tersebut masih jauh dari target. Persentase angka penerapan PHBS pada tatanan rumah tangga mengalami peningkatan dari 50,1\% tahun 2010 naik menjadi 53,9\% tahun 2011, 56,5\% pada tahun 2012, kemudian turun menjadi 55\% pada tahun 2013. Hal ini berarti anggota keluarga yang sudah menerapkan PHBS masih sangat rendah. Kementerian Kesehatan pada 2011 juga menyebutkan bahwa capaian tersebut masih dibawah indikator pencapaian yang dicanangkan oleh kebijakan Rencana Strategis pada tahun 2010-2014. Capaian target rumah yang sudah melakukan perilaku hidup bersih dan sehat didalam kehidupan sehari-harinya untuk tahun 2014 adalah sebesar 70\% (Kemenkes RI, 2017).

Rokok merupakan salah satu faktor risiko utama dari beberapa penyakit kronis yang dapat mengakibatkan kematian. Banyak penelitian sudah membuktikan bahwa merokok dapat meningkatkan risiko timbulnya berbagai penyakit yang dapat mengakibatkan kematian. Hal ini menunjukkan bahwa rokok merupakan masalah besar bagi kesehatan masyarakat. Remaja biasanya mulai mengenal rokok sejak usia SMP. Remaja kadang berpikir kalau tidak merokok maka dianggap tidak gaul. Sehingga banyak anak usia sekolah dengan santainya merokok di luar sekolah walaupun masih menggunakan seragam sekolah tanpa memperdulikan akibat dari rokok walaupun sudah banyak iklan-iklan yang menyampaikan bahwa rokok itu berbahaya bagi kesehatan. Untuk itu sebaiknya kampanye anti rokok dilaksanakan sejak dini di sekolah-sekolah (Diah, dkk. 2020).

Konsumsi rokok di Indonesia mencapai 215 miliyar batang per tahunnya. Di Indonesia ada $60 \%$ perokok, 59\% diantaranya adalah laki-laki dan $37 \%$ nya perempuan. Di Indonesia tembakau ditambah cengkeh dan bahan-bahan lain dicampur untuk dibuat rokok kretek. Bahan dasar rokok adalah tembakau. Tembakau terdiri dari berbagai bahan kimia yang dapat membuat seseorang ketagihan, walaupun mereka tidak ingin mencobanya lagi. Beberapa bahan bahkan begitu beracun sehingga beberapa pabrik "rokok" besar biasanya akan memiliki standar yang tinggi untuk membuang bahanbahan beracun yang sangat berbahaya tersebut. Jumlah perokok di Indonesia menduduki peringkat ketiga tertinggi didunia. Jumlah perokok di negara-negara berkembang jauh lebih banyak dibanding jumlah perokok di negara maju (Nasution, 2016)

Kabupaten Boalemo yang berada di Provinsi Gorontalo memiliki 7 kecamatan dan 82 desa, salah satunya adalah Kecamatan Dulupi. Desa Dulupi memiliki jumlah penduduk 4165 jiwa. Berdasarkan hasil pendataan masih ditemukan beberapa masyarakat yang tidak melakukan pola hidup sehat seperti, merokok (28,7\%), membuang sampah tidak pada tempatnya (46,3\%), dan belum memiliki jamban (25,7\%). Berdasarkan data tersebut maka dianggap perlu suatu upaya untuk meningkatkan kesadaran dan pengetahuan masyarakat Desa Dulupi tentang Perilaku Hidup Bersih dan Sehat (PHBS) serta bahaya perilaku merokok. 


\section{METODE}

Pengabdian kepada masyarakat yang dilakukan pada kegiatan ini adalah penyuluhan kesehatan dengan tema "peningkatan pengetahuan tentang pola hidup sehat dan bahaya merokok pada remaja”. Sasaran dalam kegiatan ini adalah siswa SMP Negeri 1 Dulupi yang terletak di Desa Dulupi, Kecamatan Dulupi, Kabupaten Boalemo. Usia remaja dijadikan kelompok sasaran karena usia remaja merupakan masa transisi dari anak-anak ke masa dewasa yaitu usia 10-19 tahun dengan rasa keingintahuan yang sangat besar. Dengan memberikan pengetahuan dan informasi yang benar terkait masalah kesehatan, remaja siswa diharapkan dapat menjadi agent of change baik di sekolah, keluarga maupun masyarakat. Jumlah siswa yang terlibat sebagai peserta dalam kegiatan penyuluhan sebanyak 30 orang. Peserta yang ikut dalam penyluhan dalam jumlah terbatas mengingat masih dalam masa pandemic COVID 19 dan masih dibatasinya pertemuan tatap muka di sekolah. Media yang digunakan dalam penyuluhan adalah laptop, proyektor (LCD) dan lembaran kuesioner.

Metode yang digunakan yaitu "Pretest - Penyuluhan - Posttest". Kegiatan Pretest dilakukan sebelum diberikan penyuluhan dengan membagikan kuesioner yang berisi beberapa pertanyaan terkait materi penyuluhan. Setelah itu dilanjutkan dengan kegiatan penyuluhan, dimana pemateri menjelaskan materi tentang PHBS dan bahaya perilaku merokok. Penjelasan materi dengan menggunakan metode ceramah dan dilanjutkan dengan diskusi menggunakan waktu sekitar 100 menit. Kegiatan akhir adalah posttest yang dilakukan setelah menerima materi dan istirahat. Posttest dilakukan dengan membagikan kembali kuesioner untuk dijawab oleh peserta penyuluhan.

Evaluasi kegiatan pengabdian ini dinilai dari persentase kehadiran peserta saat penyuluhan, jalannya proses penyuluhan, serta peningkatan pengetahuan yang diperoleh. Peningkatan pengetahuan dinilai dengan membandingkan hasil pretest dan posttest.

\section{HASIL DAN PEMBAHASAN}

Kegiatan pengabdian ini dilakukan pada hari Sabtu tanggal 18 September 2021 pada salah satu ruangan kelas di SMP Negeri 1 Dulupi. Pembukaan acara penyuluhan kesehatan dimulai pada pukul o9.oo WITA. Acara dibuka dengan perkenalan peserta dan informasi tentang tahapan kegiatan pengabdian. Kegiatan pengabdian ini dibagi menjadi 3 tahapan yaitu:

\section{Tahapan Awal (Pre-Even)}

Tahapan kegiatan pertama yang dilakukan yaitu dengan pembagian kuesioner yang berisi pertanyaan tentang materi PHBS dan bahaya perilaku merokok (Pretest). Hasil pretest menunjukkan bahwa masih terdapat siswa yang memiliki pengetahuan yang kurang yaitu 5\% dari jumlah total peserta. 


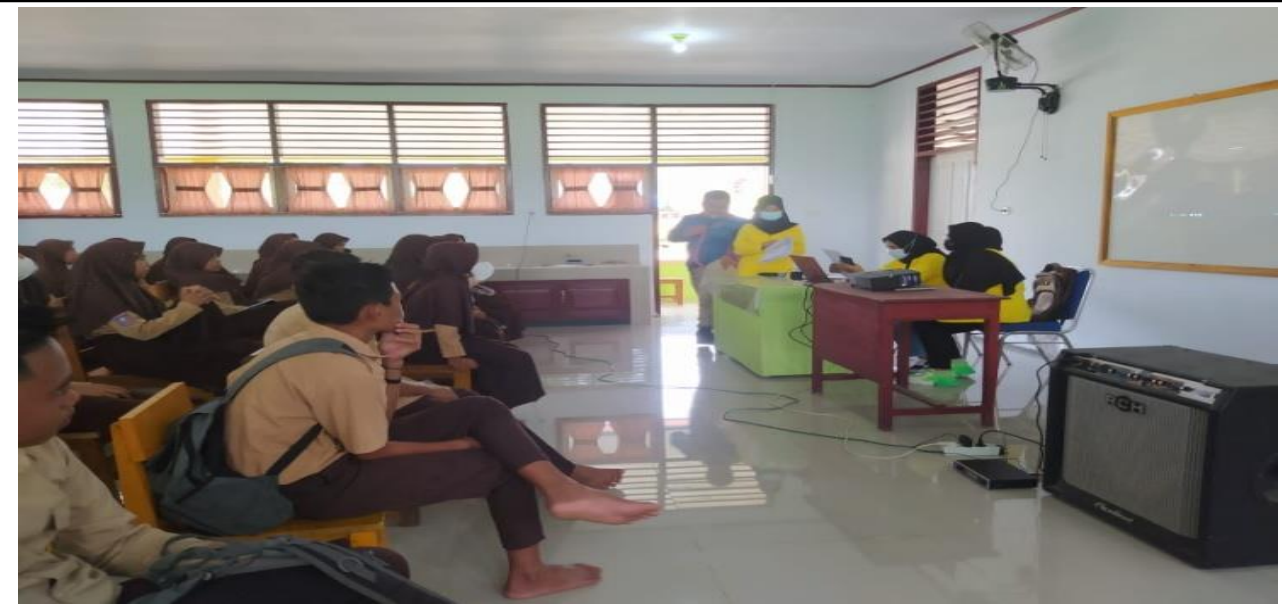

Gambar 1. Pembagian Kuesioner Pretest kepada Peserta

\section{Tahapan Penyuluhan (Even)}

Pada tahapan ini pemateri menjelaskan materi tentang PHBS dan bahaya perilaku merokok. Materi dipaparkan secara panel oleh dua orang pemateri. Saat proses penyuluhan kesehatan berlangsung, para siswa sangat antusias dalam mendengarakan dan menyimak materi yang disampaikan. Bahkan ada beberapa siswa yang tidak sabar untuk mengajukan pertanyaan. Maka setelah materi diberikan waktu untuk diskusi dan menjawab pertanyaan dari beberapa siswa. Sesi diskusi ini juga diharapkan dapat membuat para siswa lebih paham lagi dengan materi yang diberikan. Sehingga dapat mewujudkan tujuan dari kegiatan pengabdian yaitu meningkatkan pengetahuan dan kesadaran siswa tentang hidup bersih dan sehat serta bahaya dalam mengomsumsi rokok. Siswa juga diharapkan mampu menerapkan hasil pengetahuan tersebut dalam kehidupan sehari-sehari.

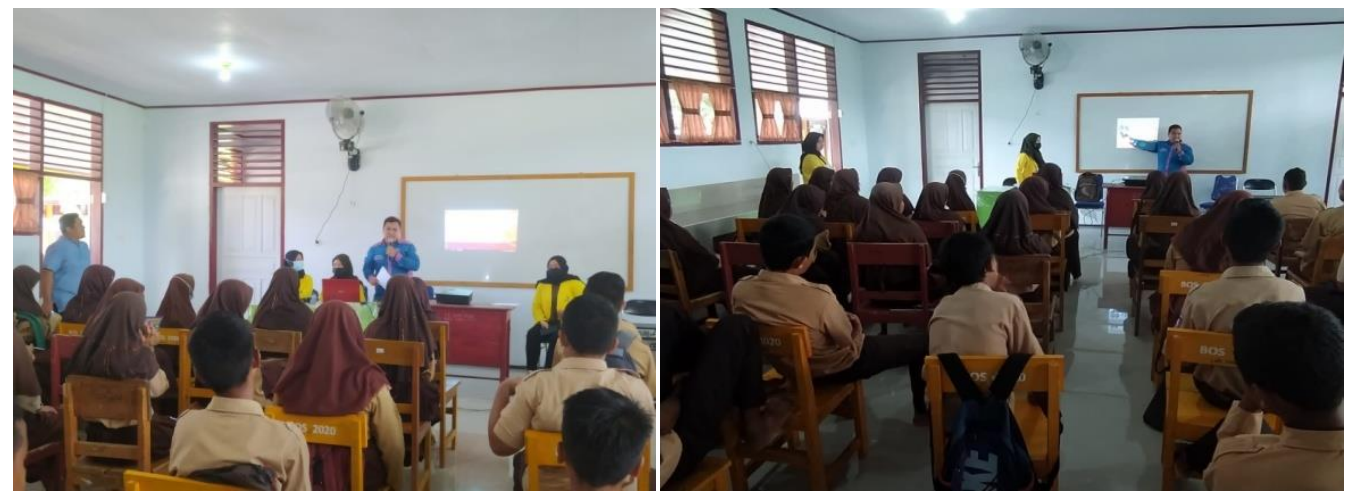

Gambar 2. Pemaparan Materi Penyuluhan

\section{Tahapan Akhir (Post-Even)}

Tahapan ini para siswa dibagikan kembali kuesioner berisi pertanyaan untuk dijawab oleh peserta penyuluhan (posttest). Hasil dari kuesioner posttest ini kemudian dibandingkan dengan jawaban pretest yang dibagikan sebelum materi penyuluhan. Pengetahuan responden setelah diberikan penyuluhan mengalami peningkatan dibandingkan sebelum penyuluhan, dimana $100 \%$ peserta telah memiliki pengetahuan yang cukup tentang PHBS dan bahaya perilaku merokok. Hal ini menunjukkan bahwa pemberian penyuluhan dapat meningkatkan pengetahuan siswa SMP tentang PHBS dan bahaya perilaku merokok. 


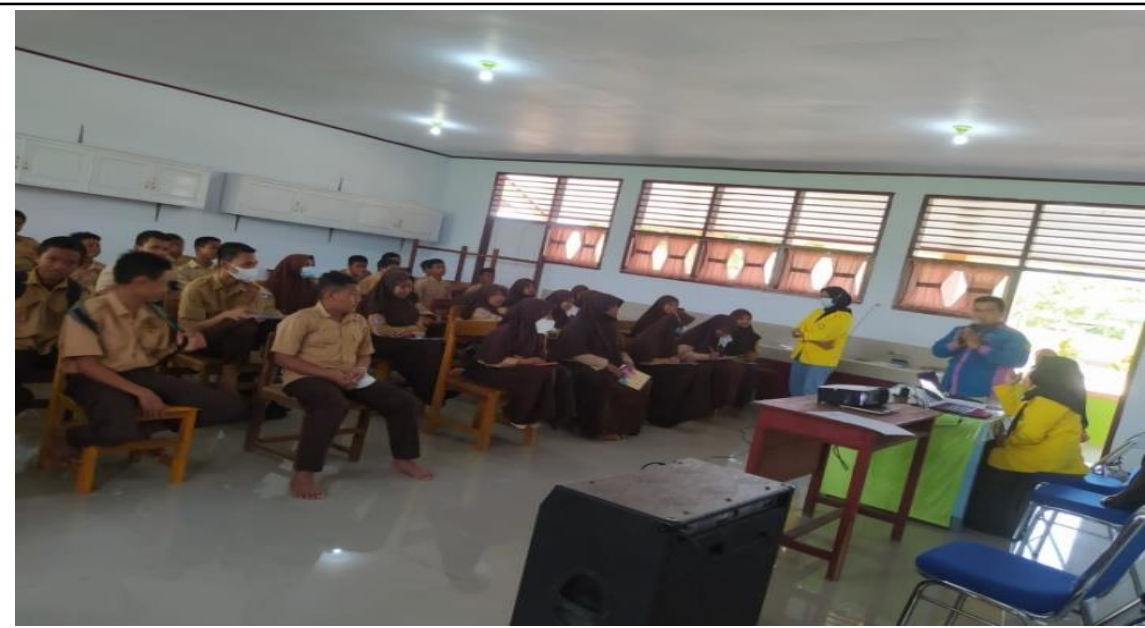

Gambar 3. Pembagian kuesioner posttest kepada peserta

Pendidikan kesehatan seperti penyuluhan merupakan upaya yang direncanakan untuk mempengaruhi orang lain, baik individu, kelompok maupun masyarakat, sehingga mau melakukan apa yang diharapkan oleh pendidik atau promotor kesehatan. Hasil yang diharapkan berupa perilaku yang baik dalam memelihara dan meningkatkan derajat kesehatan (Notoatmodjo, 2012). Hasil pengabdian ini didukung oleh penelitian Made Rismawan di Denpasar yang menyatakan bahwa sekolah memiliki peran penting sebagai penyebaran informasi ke siswa tentang pelaksanan PHBS di lingkungan sekolah atau masyarakat (Rismawan dkk, 2018).

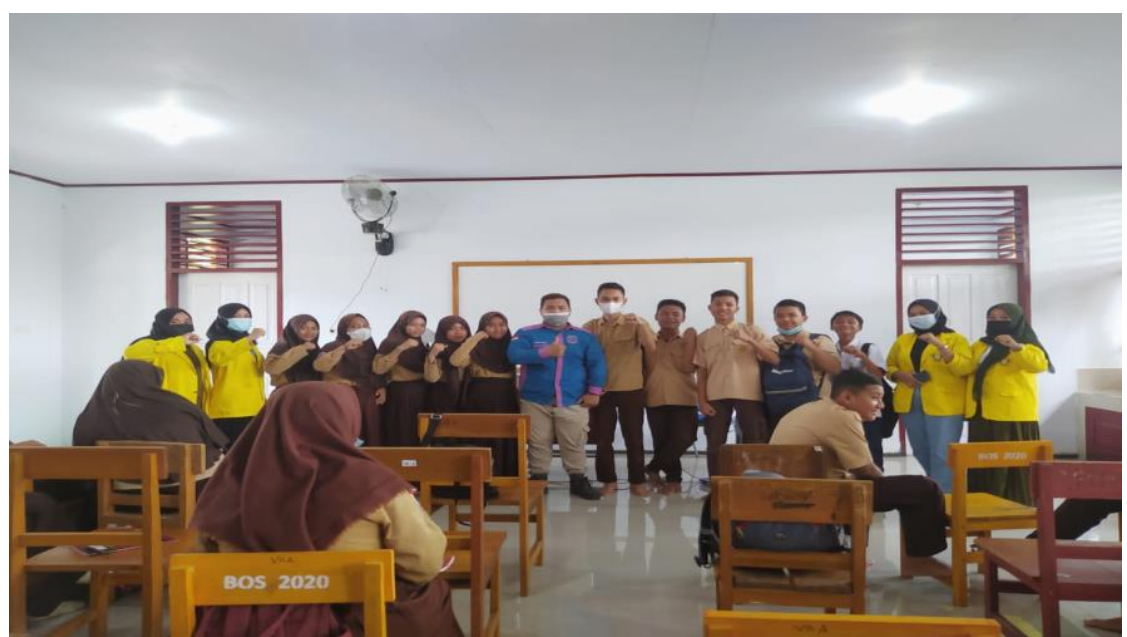

Gambar 4. Penutupan kegiatan pengabdian dengan foto bersama

\section{KESIMPULAN}

Pelaksanaan kegiatan pengabdian kepada masyarakat berupa Peningkatan Pengetahuan Siswa SMP Negeri 1 Dulupi tentang PHBS dan bahaya perilaku merokok dapat terselenggara dengan baik dan berjalan sesuai rencana kegiatan yang telah disusun sebelumnya. Kegiatan ini juga mendapat sambutan yang baik dilihat dari keaktifan peserta dalam menyimak materi dan bertanya pada saat sesi diskusi. Berdasarkan hasil kegiatan diperoleh bahwa terjadi peningkatan pengetahuan siswa setelah memperoleh 
materi penyuluhan dibandingkan dengan pengetahuan sebelum materi diberikan. Maka dari hal tersebut diharapkan siswa sekolah bisa mengetahui pentingnya melakukan Perilaku Hidup Bersih dan Sehat.

Dengan melihat keberhasilan dari kegiatan pengabdian ini dalam meningkatkan pengetahuan para siswa maka dianggap perlu untuk melakukan kegiatan seperti ini secara periodik dengan meningkatkan jumlah sasaran peserta dari beberapa sekolah. Serta meningkatkan alat peraga berupa modul pembelajaran. Sehingga akan lebih banyak lagi anak usia remaja yang dapat menjadi agent of change untuk meningkatkan derajat kesehatan masyarakat.

\section{REFERENSI}

Aeni, aqurotul, dkk. (2016). Pengaruh Pendidikan Kesehatan dengan Metode Pemutaran Video tentang PHBS Cuci Tangan Terhadap Pengetahuan dan Sikap. Sekolah tinggi ilmu kesehatan kendaL-tidak diterbitkan.

Departemen Kesehatan Republik Indonesia. (2011). Peraturan Menteri Kesehatan Republik Indonesia No. 2269/MenKes/Per/XI/2011. Jakarta: Departemen Kesehatan Republik Indonesia.

Diah Prihatiningsih, dkk. (2020). Penyuluhan Bahaya Merokok Untuk Meningkatkan Kesadaran Remaja Mengenai Dampak Buruk Rokok Bagi Kesehatan di SMP Tawakal Denpasar. Jurnal Pengabdian Kesehatan STIKES Cendekia Utama Kudus. 3(1) Januari 2020. Denpasar

Diana, Fifi Melva, dkk. (2014). Pelaksanaan Program Perilaku Hidup Bersih Dan Sehat (PHBS) Di SD Negeri oo1 Tanjung Balai Karimun. Jurnal Kesehatan Masyarakat, Septermber 2013-Maret 2014, Volume 8 Nomor 1.

Kemenkes RI, (2016) Panduan Pembina dan Penilaian Perilaku Hidup Bersih dan Sehat di Rumah Tangga.

Kemenkes RI (2016). Profil Kesehatan Indonesia.

Kemenkes RI (2017). Panduan Pembina dan Penilaian Perilaku Hidup Bersih dan Sehat di Rumah Tangga.

Nasution (2016). Perilaku Merokok Pada Remaja. Medan: Universitas Sumatra Utara Press.

Notoatmodjo, S. (2012). Promosi Kesehatan dan Perilaku Kesehatan. Jakarta: Rineka Cipta.

Rahmawati Madanih, dkk. (2019). Penyuluhan Perilaku Hidup Bersih Dan Sehta PHBS Dengan Demgan 7 Langka Cara Mencuci Tangan Yang Efektif Sekolah Paud Mawar Kelurahan Sawah Baru Cipupat Tanggerang Selatan. Jurnal Prosiding Seminar Nasional Pengabdian Masyarakat. Tanggerang

Rismawan, Made, dkk. (2018). Pelaksanaan Program Perilaku Hidup bersih dan Sehat (PHBS) pada SDN di Kota Denpasar. JRKN Vol.o2/No.o1/April/2018. 